\title{
Innovativeness of Farmers in Irrigation Scheduling for Major Plantation Crops: Analysis from Kerala State, India
}

\author{
K. Madhava Chandran ${ }^{1 *}$ and E. J. Joseph ${ }^{2}$ \\ Received: $16^{\text {th }}$ September, 2014 / Accepted : $25^{\text {th }}$ February, 2015
}

\begin{abstract}
Soil moisture stress during summer is a major factor limiting higher crop productivity in Kerala State of India. The irrigated area in the State is only $18 \%$ of the net sown area. The average productivity of many plantation crops is low, compared to the other regions of the country. For increasing crop productivity and net returns of farmers in Kerala, it is necessary to overcome crop water deficit by adopting scientific irrigation management. Under this study, 200 progressive farmers cultivating various upland crops in different agro ecological zones of Kerala were interviewed using a semi-structured questionnaire on irrigation management practices adopted by them. The irrigation schedule adopted by the farmers was compared with the recommendations for various crops, and accordingly, their innovativeness with regard to the quantity of water application and irrigation interval was analyzed. The irrigation methods adopted were also studied. The results revealed that even though a good proportion of coconut and arecanut farmers irrigate at intervals specified in the recommendations for the crops, majority of them are not applying quantity of water according to the recommendation. As far as irrigation methods are concerned, most of the arecanut and coconut farmers practice basin irrigation, which is a good method for these crops. A good proportion of coffee and cardamom farmers adopt scientific irrigation scheduling and improved irrigation methods like sprinkler, which may be attributed to the remunerative market price of the produce and better extension support available for them. The importance of profitability in farming for adopting scientific irrigation practices is evident from the study. Adoption of water saving drip irrigation by the farmers is insignificant, even when financial subsidy is provided by the Agriculture Department for promoting this irrigation technique.
\end{abstract}

Key words: Irrigation scheduling, Innovativeness of farmers, Irrigation methods

\section{INTRODUCTION}

Kerala State lies on the south-west coast of India between $8^{\circ} 18^{\prime}$ and $12^{\circ} 48^{\prime} \mathrm{N}$ latitude and $74^{\circ} 52^{\prime}$ and $77^{\circ} 22^{\prime} \mathrm{E}$ longitude. Within a narrow strip of 15 to $120 \mathrm{~km}$ width and about $550 \mathrm{~km}$ length, the State occupies a land area of 38863 sq km covering three distinct topographic zones; the coastal lowland ( $<7.5 \mathrm{~m}$ above MSL), the midland ( $7.5 \mathrm{~m}$ to $75 \mathrm{~m}$ above MSL) and the Western Ghats highland ( $>75 \mathrm{~m}$ above MSL). Kerala experiences humid tropical climate, characterized by high annual rainfall of about $3000 \mathrm{~mm}$ and high atmospheric humidity throughout the year. The State is delineated into 13 agro ecological zones. The crops cultivated

are similar to that in most other humid tropical regions of the world. Kerala has a high population density of 859 per sq $\mathrm{km}$, which is the major factor contributing to a cultivated area of as high as $55 \%$ of the total geographical area. Perennial crops like coconut, rubber, arecanut, coffee, tea, cardamom, black pepper, cashew, cocoa, various tree spices etc., which are mainly cultivated in the uplands, occupy about $85 \%$ of the agricultural area in the State. Of these, coconut and rubber contribute about $39 \%$ and $26 \%$ respectively of the agricultural area. The food crops comprising rice, pulses, millets, vegetables, tapioca, yams etc., which 
are grown in the valleys, occupy only about 13 $\%$ of the gross cropped area (Farm Information Bureau, Govt. of Kerala, 2008).

Soil moisture stress during summer season extending to six months is a major limiting factor for higher crop productivity in Kerala. Under normal climatic conditions, the water deficit for coconut in the State during the summer season is estimated to range from 259 $\mathrm{mm}$ to $546 \mathrm{~mm}$, for arecanut about $650 \mathrm{~mm}$, while black pepper, coffee, tea and cardamom have water deficit in the range of 407 to 613 in various districts where they are cultivated (Varadan,1997). Farmers are mostly not aware of proper irrigation management practices in Kerala. The irrigated area in the State is only $18 \%$ of the net sown area (Farm Information Bureau, Govt. of Kerala, 2008). For the main upland crops such as coconut and arecanut, the irrigated area is only about $19 \%$ and 32 $\%$ of their cultivated area respectively (Farm Information Bureau, Govt. of Kerala, 2008). The average productivity of many plantation crops is low, compared to the other regions of the country. The mean annual yield of coconut in the State of Maharashtra (87 nuts/tree), Andhra Pradesh (66 nuts/tree) and Tamil Nadu (52 nuts/ tree) is significantly above the yield of 38 nuts/ tree obtained in Kerala (State Planning Board, Govt. of Kerala, 2006). In order to increase crop productivity and net returns of farmers in Kerala, it is vital to overcome crop water deficit by adopting irrigation during summer. Most of the coconut farmers in Kerala have been found to be unaware of the scientific irrigation recommendation.

This paper reports the results of a study carried out in Kerala on the irrigation schedule (quantity of irrigation water applied and irrigation interval) adopted by farmers, and accordingly, analyze their innovativeness in irrigation management.

\section{MATERIALS AND METHODS}

200 progressive farmers cultivating various upland crops were selected through simple random sampling from different agro ecological zones in Kerala based on the list provided by the Agriculture Department, Govt. of Kerala. Personal interviews were carried out with them using a semi-structured questionnaire, which contained details on method of irrigation practiced, irrigation interval and quantity of water applied for different crops.

The irrigation recommendation in the 'Package of Practices (POP) Recommendation for Crops' in the State is of a general nature, and not specific to different agro ecologic zones (Kerala Agricultural University, 2002). In order to overcome this limitation, Varadan et al (1990) have empirically worked out the locationspecific crop evapotranspiration (ETc) on per day basis for various crops, and accordingly, worked out the irrigation schedule of crops in different summer months, taking into account the soil and climatic conditions in different districts of Kerala. Water requirement of crops is considered as crop evapotranspiration (ETc) on per day basis.

The quantity of water applied by farmers was computed on per day basis for various crops using the data on the irrigation schedule reported by them. This was compared with the quantity of water required for different crops (on per day basis) based on the irrigation schedule specified under POP recommendation. For those crops, where there is no POP recommendation, CWRDM irrigation schedule prepared by the Centre for Water Resources Development and Management (Varadan et al., 1990) was adopted for working out the quantity of irrigation water.

The innovativeness of the progressive farmers on scientific irrigation management has also been analyzed in this study. Farmers irrigating $80 \%$ and more of the POP recommendation / CWRDM schedule were considered as "very innovative", 50 to $79 \%$ of POP recommendation / CWRDM schedule as "innovative", and those irrigating less than $50 \%$ and more than $100 \%$ of the POP recommendation / CWRDM schedule as "non innovative" (Satadal Das 
Gupta, 1989). For irrigation interval also, the same criteria was adopted in categorizing "very innovative", "innovative" and "non-innovative" farmers. Farmers applying more water than the requirement are wasting water, without any additional influence on the crop. Hence, they were also included in the "non-innovative" category.

\section{RESULTS AND DISCUSSSION}

Farmers under this study are generally not aware of scientific irrigation recommendation for crops, while those who are aware do not usually adopt it. They irrigate based on their traditional knowledge. The irrigation method adopted, quantity of irrigation water used and irrigation interval followed for different crops are mostly based on practical experience of farmers and information generated through inter personal communication.

Table 01 gives details of irrigating farmers in the sample selected for study. Only those crops having $25 \%$ and more of irrigating farmers have been considered for analysis. It may be observed from Table 1 that $92 \%$ of cardamom farmers and $71 \%$ of coconut farmers irrigate their crop, while only $26 \%$ of pepper farmers practice irrigation.

\section{Quantity of irrigation water applied by farmers}

Coconut: The quantity of water, calculated on the basis of the POP recommendation and
CWRDM schedule, work out to 175 litres/ day/plant. It can be made out from Table 2 that $64.3 \%$ of coconut farmers apply less than $50 \%$ of the crop water requirement and only $14.3 \%$ of farmers irrigate in the range of 50 to $79 \%$ of the requirement as per the POP recommendation. Table 2 also shows that a very high proportion of farmers $(83.3 \%)$ fall in the "non innovative" category $(64.3 \%$ farmers irrigating less than $50 \%$ of POP recommendation and $19 \%$ farmers irrigating more than $100 \%$ of POP recommendation). Only $2.4 \%$ of farmers are "very innovative" (Table 02). They irrigate $80 \%$ of POP recommendation From this, it may be inferred that majority of the coconut farmers are non-innovative with regard to the quantity of irrigation water used.

Arecanut: In the case of arecanut, the quantity of water based on the POP recommendation works out to 33 litres/ day/ plant. It may be seen from Table 2 that $47 \%$ of arecanut farmers irrigate less than $50 \%$ of the crop water requirement. $15.5 \%$ farmers have an irrigation rate in the range of 50 to $79 \%$ of the POP recommendation. The table also shows that $81.4 \%$ farmers are "non innovative" regarding the quantity of irrigation water applied (47. $2 \%$ farmers irrigating less than $50 \%$ of POP recommendation and $34.2 \%$ farmers irrigating above $100 \%$ of POP recommendation). Only $3.1 \%$ of farmers are "very innovative" (Table 02) with respect to quantity of water applied for the crop.

Table 01. Details of irrigating farmers

\begin{tabular}{lc}
\hline \multicolumn{1}{c}{ Crop } & Irrigating farmers $(\%)^{*}$ \\
\hline Coconut & 71 \\
Arecanut & 45 \\
Coffee & 52 \\
Cardamom & 92 \\
Black Pepper & 26 \\
\hline
\end{tabular}

\footnotetext{
* Percentage of total
} 
Table 02. Quantity of irrigation water applied by coconut and arecanut farmers.

\begin{tabular}{|c|c|c|c|}
\hline \multicolumn{2}{|l|}{ Coconut } & \multicolumn{2}{|l|}{ Arecanut } \\
\hline Quantity of water/day/plant (\%)* & Farmers (\%) & Quantity of water/day/plant (\%)* & Farmers (\%) \\
\hline $0-9$ & 33.3 & $0-9$ & 15.8 \\
\hline $10-19$ & 14.3 & $10-19$ & nil \\
\hline $20-29$ & 9.5 & $20-29$ & 12.5 \\
\hline $30-39$ & 2.4 & $30-39$ & 15.8 \\
\hline $40-49$ & 4.8 & $40-49$ & 3.1 \\
\hline $50-59$ & 9.5 & $50-59$ & 6.2 \\
\hline $60-69$ & nil & $60-69$ & 3.1 \\
\hline $70-79$ & 4.8 & $70-79$ & 6.2 \\
\hline $80-89$ & 2.4 & $80-89$ & 3.1 \\
\hline $90-100$ & nil & $90-100$ & nil \\
\hline More than 100 & 19.0 & More than 100 & 34.2 \\
\hline Total & 100 & Total & 100 \\
\hline Innovativeness of coconut farmers & Farmers (\%) & Innovativeness of arecanut farmers & Farmers (\%) \\
\hline Very innovative & 2.4 & Very innovative & 3.1 \\
\hline Innovative & 14.3 & Innovative & 15.5 \\
\hline Non-innovative & 83.3 & Non-innovative & 81.4 \\
\hline Total & 100 & Total & 100 \\
\hline
\end{tabular}

* expressed as percentage of per day quantity computed from the POP recommendation for the crop

Hence, similar to farmers cultivating coconut, a very high proportion of arecanut farmers are also non-innovative in irrigation water use for the crop. Coconut and arecanut are primarily cultivated as homestead crops in Kerala, where water availability is usually not sufficient to meet various demands, especially irrigation, which consumes more water than for domestic use. It is also cumbersome for farmers to practice irrigation for these crops, since they are mainly cultivated on undulating terrain in the State. This is supported by data, which shows that the area under irrigation in coconut and arecanut in Kerala is only $19 \%$ and $32 \%$ of the cropped area respectively (Farm Information Bureau, Govt. of Kerala, 2008). The market value of agricultural produce has also been low and stagnant over many years for these crops. Newbery and Stiglitz (1981), while reporting on adoption and utilization of soil and water conservation practices by risk aversive farmers, suggest that risk resulting from price instability is inimical to adoption. Rather than focusing on their land base, farmers diversify their incomes through off-farm employments (Robinson and Barry, 1987). The low price of produce for coconut and arecanut in Kerala make many farmers practice other income generative activities for their livelihood. Hence, they can't be expected to have interest in improved agricultural practices.

Studies have reported the importance of extension education in adoption of agricultural practices (Jamison and Moock, 1984; Rahm and Huffman, 1984). Extension support available to farmers cultivating crops like coconut and arecanut in Kerala is primarily focused on financial assistance such as subsidies and loans, and very less on technical guidance related to aspects such as scientific water management. 
The above mentioned factors will influence a farmer's decision on adopting irrigation. In addition, irrigating farmers may not be in a position to apply the required quantity of water due to water scarcity being frequently experienced in Kerala during summer season.

Coffee: There is no POP recommendation for quantity of irrigation water for coffee. As per CWRDM irrigation schedule, the quantity of water required for the crop is 17 litres/day/ plant. Table 03 shows that even though there are no farmers applying 80 to $89 \%$ of CWRDM schedule, $15.3 \%$ farmers are "very innovative" (irrigating 90-100\% of the schedule) and 31.1\% "innovative", totaling to $46.4 \%$ farmers with a favourable attitude towards water requirement of the crop. It can also be made out from Table 3 that, when compared to the other ranges of water application, a higher proportion ( $23.4 \%$ farmers) applies $60-69 \%$ of CWRDM irrigation schedule. Only $38.3 \%$ of coffee farmers apply water less than $50 \%$ of the crop water requirement (Table 3 ), while the proportion of farmers irrigating at this rate is more in the case of coconut $(64.3 \%)$ and arecanut (47\%). Farmers applying more water than the requirement are also less in coffee (Table 03), when compared to coconut and arecanut (Table 02). This indicates that coffee farmers have more scientific orientation towards irrigation management.

Table 03. Quantity of irrigation water applied by coffee and cardamom farmers

\begin{tabular}{|c|c|c|c|}
\hline \multicolumn{2}{|c|}{ Coffee } & \multicolumn{2}{|c|}{ Cardamom } \\
\hline $\begin{array}{c}\text { Quantity of water/day/ } \\
\text { plant }(\%)^{*}\end{array}$ & Farmers $(\%)$ & $\begin{array}{c}\text { Quantity of water/day/ } \\
\text { plant }(\%)^{*}\end{array}$ & Farmers $(\%)$ \\
\hline $0-9$ & 15.3 & $0-9$ & 10 \\
\hline $10-19$ & 7.7 & $10-19$ & 10 \\
\hline $20-29$ & 15.3 & $20-29$ & 30 \\
\hline 30-39 & nil & $30-39$ & 10 \\
\hline $40-49$ & nil & $40-49$ & 10 \\
\hline $50-59$ & nil & $50-59$ & 10 \\
\hline $60-69$ & 23.4 & $60-69$ & nil \\
\hline $70-79$ & 7.7 & $70-79$ & 10 \\
\hline $80-89$ & nil & $80-89$ & nil \\
\hline $90-100$ & 15.3 & $90-100$ & 10 \\
\hline More than 100 & 15.3 & More than 100 & nil \\
\hline Total & 100 & Total & 100 \\
\hline $\begin{array}{l}\text { Innovativeness of } \\
\text { coffee farmers }\end{array}$ & Farmers (\%) & $\begin{array}{l}\text { Innovativeness of } \\
\text { cardamom farmers }\end{array}$ & Farmers (\%) \\
\hline Very innovative & 15.3 & Very innovative & 10 \\
\hline Innovative & 31.1 & Innovative & 20 \\
\hline Non-innovative & 53.6 & Non-innovative & 70 \\
\hline Total & 100 & Total & 100 \\
\hline
\end{tabular}

* expressed as percentage of per day quantity computed from CWRDM schedule for the crop 
Under Kerala conditions, where the average annual rainfall is about $3000 \mathrm{~mm}$, crops like coconut and arecanut can give satisfactory yield through adoption of in situ rainwater conservation measures, without necessarily irrigating during summer season (December to May). However, coffee requires irrigation during summer for blossoming, fertilization and berry growth, which contributes to good crop yield. The crop is mostly sprinkler-irrigated and the firms supplying sprinklers as well as Coffee Board give advice to farmers on the irrigation schedule. This is especially relevant for an energy consuming irrigation technique like sprinkler. All this could have contributed to the development of scientific orientation on quantity of irrigation water among the coffee growers.

Cardamom: Cardamom also does not have a POP recommendation for quantity of irrigation water. As per CWRDM schedule, it works out to 4 litres/day/plant. It can be made out from Table 3 that $70 \%$ farmers are "non-innovative" regarding the quantity of water use for the crop. However, it may be noted that $10 \%$ farmers fall in the "very innovative" and 20\% in the "innovative" categories with respect to a scientific perspective on quantifying irrigation water for cardamom. This can be compared with coconut and arecanut, where less than $20 \%$ farmers are "innovative" on the quantity of water applied (Table 02). It can also be observed from Table 03 that none of the cardamom farmers irrigate above $100 \%$ of the requirement, indicating their orientation to economize water use. Cardamom is primarily irrigated using sprinklers. Similar to coffee, cardamom farmers also get scientific advice on irrigation management from sprinkler irrigation firms and institutions like Spices Board, helping them to adopt scientific water management.

From the analysis, it can be inferred that coffee and cardamom farmers exhibit more innovativeness than coconut or arecanut farmers in irrigating as per crop water requirements. Pepper: Water requirement of the crop works out to 11 litres/day/plant and 8 litres/day/plant as per POP recommendation and CWRDM schedule respectively. Table 04 shows the quantity of water applied by pepper farmers. $40 \%$ farmers are "innovative" since they irrigate in the range of 60 to $70 \%$ of the crop water requirement. Pepper is quite sensitive to moisture stress. This may be why pepper farmers in this study are more innovative in water use than coconut or arecanut farmers.

\section{Irrigation interval adopted by farmers}

Coconut: For coconut, the POP recommendation includes irrigation intervals of $3,4,5,7,8$ and 9 days, depending upon the soil type / location. Table 5 shows that $50 \%$ farmers adopt intervals of $3,4,7,8$ and 9 days for coconut, making them "very innovative", while $4.8 \%$ are "innovative" in adopting recommended irrigation interval for the crop. However, only $16.7 \%$ farmers come within the "very innovative" and "innovative" categories together regarding quantity of water application for the crop.

Table 04. Quantity of irrigation water applied by pepper farmers

\begin{tabular}{lc}
\hline \multicolumn{1}{c}{ Quantity of water/day/plant $(\%)^{*}$} & Farmers $(\%)$ \\
\hline $60-70$ & 40 \\
More than 100 & 60 \\
Total & 100 \\
Innovativeness of farmers & Farmers $(\%)$ \\
Innovative & 40 \\
Non-innovative & 60 \\
Total & 100 \\
\hline
\end{tabular}

* expressed as percentage of per day quantity computed from POP recommendation for the crop 
Table 05. Irrigation interval adopted by farmers

\begin{tabular}{|c|c|c|c|c|c|c|c|c|c|c|}
\hline Item & Coconut & $\begin{array}{c}\text { Farmers } \\
(\%)\end{array}$ & Arecanut & $\begin{array}{c}\text { Farmers } \\
(\%)\end{array}$ & Coffee & $\begin{array}{c}\text { Farmers } \\
(\%)\end{array}$ & Cardamom & $\begin{array}{c}\text { Farmers } \\
(\%)\end{array}$ & Pepper & $\begin{array}{c}\text { Farmers } \\
(\%)\end{array}$ \\
\hline \multirow[t]{4}{*}{$\begin{array}{l}\text { Irrigation interval } \\
\text { (days) }\end{array}$} & 1 and 2 & 21.5 & 1 and 2 & 22.0 & 1 & 20.0 & 1,2 and 3 & 60.0 & 5 and 7 & 60.0 \\
\hline & $\begin{array}{l}3,4,7,8 \\
\text { and } 9\end{array}$ & 50.0 & 3,4 and 7 & 62.5 & 3 and 7 & 80.0 & 4 and 7 & 30.0 & 10 & 20.0 \\
\hline & $\begin{array}{l}\text { More } \\
\text { than } 9\end{array}$ & 28.5 & $\begin{array}{l}\text { More } \\
\text { than } 7\end{array}$ & 15.5 & - & - & $\begin{array}{l}\text { More } \\
\text { than } 8\end{array}$ & 10.0 & $\begin{array}{l}\text { More } \\
\text { than } 10\end{array}$ & 20.0 \\
\hline & Total & 100 & Total & 100 & Total & 100 & Total & 100 & Total & 100 \\
\hline $\begin{array}{l}\text { Innovativeness } \\
\text { of farmers }\end{array}$ & & $\begin{array}{l}\text { Farmers } \\
(\%)\end{array}$ & & $\begin{array}{l}\text { Farmers } \\
(\%)\end{array}$ & & $\begin{array}{l}\text { Farmers } \\
(\%)\end{array}$ & & $\begin{array}{l}\text { Farmers } \\
(\%)\end{array}$ & & $\begin{array}{l}\text { Farmers } \\
(\%)\end{array}$ \\
\hline Very innovative & Coconut & 50.0 & Arecanut & 62.5 & Coffee & 80.0 & Cardamom & 30.0 & Pepper & 60.0 \\
\hline Innovative & & 4.8 & & 9.4 & & nil & & 40.0 & & 20.0 \\
\hline Non-innovative & & 45.2 & & 28.1 & & 20.0 & & 30.0 & & 20.0 \\
\hline Total & & 100 & & 100 & & 100 & & 100 & & 100 \\
\hline
\end{tabular}

Arecanut: The POP recommendation on irrigation interval for arecanut in Kerala ranges from 3 to 7 days. It can be made out from Table 5 that $62.5 \%$ arecanut farmers are "very innovative", adopting irrigation interval in the range of 3 to 7 days, while $9.4 \%$ farmers fall in the "innovative" category. This is in contrast to only $18.6 \%$ of arecanut farmers falling within the "very innovative" and "innovative categories" for quantity of water use.

Coffee: According to CWRDM irrigation schedule, irrigation intervals for coffee work out to 3,7 and 9 days. Table 05 shows that $80 \%$ of farmers are "very innovative", irrigating in 3 to 7 days interval. It has been already observed in Table 03 that about $46 \%$ farmers show innovativeness with respect to the quantity of water applied for the crop. Hence, it may be inferred that a good proportion of coffee farmers are interested in scientific irrigation scheduling. Remunerative market value and extension support available to coffee farmers can be the factors attributed to this trend.

Cardamom: According to CWRDM schedule, the crop needs irrigation at an interval of 4 , 7 and 8 days. $30 \%$ farmers irrigate at 4 to 7 days interval (Table 05), making them "very innovative". It may also be observed from Table 5 that $40 \%$ farmers are "innovative" in adoption of irrigation interval for the crop. Hence, on the whole, $70 \%$ of cardamom farmers exhibit innovativeness in adopting irrigation interval on a scientific basis. However, $70 \%$ farmers are found to be "non-innovative" regarding quantity of water application for the crop.

Pepper: According to the POP recommendation, pepper has to be irrigated once in 8 to 10 days. Table 05 reveals that $20 \%$ farmers irrigate at 10 days interval. The table also indicates that $60 \%$ of the farmers are "very innovative" and 20\% "innovative" in adopting scientific irrigation interval for the crop. Regarding quantity of water applied, 40\% farmers are "innovative". Adoption of scientific irrigation scheduling by many farmers may be attributed to the cash crop nature of pepper, which gives higher returns than coconut or arecanut.

\section{Irrigation methods adopted by farmers}

Table 6 shows the proportion of farmers adopting different irrigation methods for crops. For arecanut and coconut, majority adopt basin irrigation, which is the method for these crops as per POP recommendation. About $16 \%$ of farmers adopt channel (furrow) irrigation for arecanut, which is also suitable for this closely spaced crop (Table 06). 
Table 06. Irrigation methods adopted by farmers

\begin{tabular}{lccccccc}
\hline \multirow{2}{*}{ Crop } & \multicolumn{7}{c}{ Farmers (\%) adopting different irrigation methods * } \\
\cline { 2 - 8 } & Basin & Sprinkler & Micro sprinkler & Drip & Channel & Flood & Total \\
\hline Coconut & 67.5 & 21.6 & nil & 3.3 & nil & 7.6 & 100 \\
Arecanut & 49.1 & 25.7 & nil & nil & 16.2 & 9.0 & 100 \\
Coffee & 26.9 & 62.5 & nil & 5.2 & nil & 5.4 & 100 \\
Cardamom & 39.8 & 29.5 & 23.1 & 7.6 & nil & nil & 100 \\
Pepper & 28.9 & 36.5 & nil & 7.6 & 21.2 & 5.8 & 100 \\
\hline
\end{tabular}

* Percentage of total

About $22 \%$ of farmers adopt sprinkler irrigation for coconut. Sprinkler irrigation for a widely spaced crop like coconut, which requires irrigation only in the basin area, where the active roots are concentrated, leads to wastage of water in the inter space of the crop. Hence, it is not an efficient irrigation method for coconut, when cultivated as a mono crop.

None of the farmers have adopted drip irrigation for arecanut, while only $3.3 \%$ of farmers have adopted it for coconut (Table 06). This is the condition, even when considerable amount of subsidy is being provided by the Agriculture Department for promoting drip irrigation for many years in Kerala. In cardamom and coffee, (Table 06) many farmers adopt sprinkler irrigation (including micro sprinkler in the case of cardamom), which is the method as per POP recommendation for these crops.

From this, it can be inferred that, by and large, the farmers are adopting proper irrigation methods for their crops.

\section{CONCLUSIONS}

This study revealed that even though a good proportion of coconut and arecanut farmers irrigate at intervals specified in the POP them are not applying the quantity of water according to the recommendation. As far as irrigation methods are concerned, most of the arecanut and coconut farmers practice basin irrigation, which is a good method for these crops. Adoption of drip irrigation for crops is poor, even when financial subsidy is provided by the Agriculture Department for promoting this irrigation technique. A good proportion of coffee and cardamom farmers adopt scientific irrigation scheduling and improved irrigation methods like sprinkler, which may be due to the remunerative market price of the produce and better extension support available for them. The importance of profitability from crop production for motivating farmers to adopt scientific water management practices is evident from the study

\section{ACKNOWLEDGEMENT}

The authors are thankful to the Indian National Committee on Irrigation and Drainage (INCID) and Ministry of Water Resources, Govt. of India for providing financial assistance for the research project. We also express our gratitude to Dr. N. B. Narasimha Prasad, Executive Director, Centre for Water Resources Development and Management, Kozhikode, Kerala, India for the support and encouragement given to us. recommendations for the crops, majority of

\section{REFERENCES}

Farm Information Bureau, Govt. of Kerala, India (2008). Farm Guide

Jamison, D. and Moock, P. R (1984). Farmer education and farm efficiency in Nepal: The role of schooling, extension services and cognitive skills. World Development: 67-86. 
Kerala Agricultural University (2002). Package of practices recommendation: crops, $12^{\text {th }}$ edition, Kerala Agricultural University, Thrissur, Kerala, India. 278 p.

Newbery, D. M. G. and Stiglitz, J. E (1981). The theory of commodity price stabilization: A study in the economics of risk. Clarendon press, Oxford. pp. 20-21.

Rahm, W. and Huffman, W (1984). The adoption of reduced tillage: The role of human capital and other variables, American Journal of Agricultural Economics, 66: 405-413.

Robinson, L. J. and Barry P. J (1987). The competitive firm's response to risk. Macmillan Publishing Co., New York. pp. 27

Satadal Das Gupta (1989). Diffusion of agricultural innovations in village India, Wiley Eastern India Ltd., New Delhi. 185 p.

State Planning Board, Govt. of Kerala, India (2006). Economic review 2006. 620 p.

Varadan, K. M (1997). Soil-crop-climate approach for estimation of water deficit for plantation and other upland crops of Kerala, In: Proceedings, International Tropical Crop Research and Development, 1: 1-5.

Varadan K.M, Madhava Chandran, K. and Lakshmanan, K (1990). User guide on farm irrigation scheduling for upland crops of Kerala, Centre for Water Resources Development and Management, Kozhikode, Kerala, India. 80 p. 